\title{
Prevention of Pyelonephritis by Water Diuresis: Evidence for the Role of Medullary Hypertonicity in Promoting Renal Infection*
}

\author{
Vincent T. Andriole $†$ and Franklin H. Epstein $\$$ \\ (From the Department of Internal Medicine, Yale University School of Medicine, New \\ Haven, and the Veterans Administration Hospital, West Haven, Conn.)
}

The medulla of the kidney is much more susceptible to infection than the cortex $(1-5)$. The unique vulnerability of the renal medulla has been ascribed in the past to its anatomical location (6), to its relatively poor circulation (7), and to its chemical composition, in particular to its content of ammonia and ammonia-producing enzymes that inhibit the action of complement (8).

The present experiments suggest that the susceptibility of the medulla to infection is determined at least in part by another of its properties, namely, its habitual hypertonicity. A simple method for inducing chronic water diuresis in rats has provided a model for studying many aspects of experimental pyelonephritis. Renal infection in rats can be prevented by decreasing the normally hypertonic environment of the renal medulla through sustained water diuresis.

\section{Methods}

Animals. White female Sprague-Dawley strain rats, weighing 150 to $200 \mathrm{~g}$ were used. Animals were weighed on the first and last days of each experiment. All animals were fed Purina lab chow pellets and tap water ad libitum.

Water diuresis. Chronic water diuresis was induced in rats by the simple method of adding $5 \%$ glucose to their drinking water. The volume of fluid intake and

\footnotetext{
* Submitted for publication July 14, 1964; accepted September 14, 1964.

Presented in part at the joint national meeting of the American Federation for Clinical Research and the American Society for Clinical Investigation, Atlantic City, N. J., May 1964, and at the Second International Symposium on the Biology of Pyelonephritis, Boston, Mass., June 1964.

Aided by grants E 1850, AI 05585, HE 00834, and AM 06397 from the U. S. Public Health Service.

$\dagger$ Clinical Investigator, Veterans Administration Hospital, West Haven, Conn.

¥ Recipient of a U. S. Public Health Service Research Career Award.
}

urine output was measured daily for each rat. Urine samples were analyzed for glucose with Clinitest reagent and for osmolality with a Fiske osmometer. Samples of blood were obtained from the abdominal aorta of rats anesthetized with pentobarbital and were analyzed for glucose by the Nelson-Somogyi method (9). In some instances, urine samples were analyzed for $\mathrm{pH}$ with a Beckman $\mathrm{pH}$ meter, model $\mathrm{G}$.

Organisms. The strains of Candida albicans (B-311) and Staphylococcus aureus (Giorgio) have been maintained in this laboratory for 5 years, and details of their handling have been described previously $(4,10)$. The inocula were prepared in the following manner. Cells of Candida albicans from $2 \%$ glucose, $1 \%$ neopeptone agar slants, incubated at $37^{\circ} \mathrm{C}$ for 24 hours, were suspended in physiologic saline. The number of cells in this suspension was determined by direct hemocytometer counts in a Spencer Bright-Line Neubauer counting chamber, and serial dilutions in physiologic saline were made so that the final inoculum contained $10^{\circ}$ organisms per $\mathrm{ml}$, the exact number being determined by standard pour plate enumeration techniques. The inoculum of Staphylococcus aureus was prepared from a nutrient broth culture, incubated at $37^{\circ} \mathrm{C}$ for 18 to 20 hours, and contained $2 \times 10^{8}$ cells per $\mathrm{ml}$. Each animal was challenged with a $0.5-$ or $1.0-\mathrm{ml}$ inoculum of either Candida or Staphylococci, respectively, injected into a lateral tail vein. These inocula are known to infect the renal medulla of normal rats $(11,12)$.

Microbiological and pathological studies. Most animals were killed 8 days after challenge. Some, however, were killed at 2 and 6 hours and at 1,2, and 5 days after intravenous Staphylococcal challenge.

Sterile technique was maintained during all surgical procedures. Under pentobarbital anesthesia, the abdominal wall was cleansed with $70 \%$ alcohol and incised so that the entire urinary tract was exposed. After urine and blood were collected in some animals, the kidneys, and in some instances, liver and spleen, were removed and placed in Petri dishes for macroscopic examination and sectioning. A midline longitudinal section was made in some kidneys. One-half of the kidney was fixed in $10 \%$ formol. These specimens were serially sectioned, and every tenth section was mounted and stained with hematoxylin-eosin for histologic examination. The remaining half of the kidney was placed in a Teflon tissue homogenizer and ground in $4.5 \mathrm{ml}$ 
of $0.85 \%$ sodium chloride solution until a homogeneous suspension was obtained. Whole kidneys were cultured after homogenization with $9.0 \mathrm{ml}$ of saline. These concentrations represented a $10^{-1}$ dilution. Subsequent tenfold dilutions were prepared in saline solution. Agar pour plates were made from these dilutions, and colony counts were determined after incubation for 48 hours.

Each specimen of whole spleen or approximately $1 \mathrm{~g}$ of liver was weighed, diluted $1: 10$ in physiologic saline, homogenized, and quantitatively cultured as already described.

Urine culture. Immediately after opening the abdominal cavity a small quantity of urine was aspirated through the bladder wall. One loopful of this was streaked on blood and desoxycholate or trypticase soy agar. In certain animals serial dilutions of urine were made in nutrient broth, and pour plates were made for final bacteriological counts.

Blood cultures were taken by direct heart puncture. Pour plates containing $0.1 \mathrm{ml}$ of blood were incubated for 48 hours, and the number of colonies was recorded.

Criteria of infection. Kidneys were considered infected when they contained $5 \times 10^{4}$ or more colonies. Urine cultures were considered positive when ten or more colonies were found on the streaked plate. This concentration is equivalent to $10^{3}$ to $10^{4}$ colonies per $\mathrm{ml}$ of urine. Blood cultures were considered positive
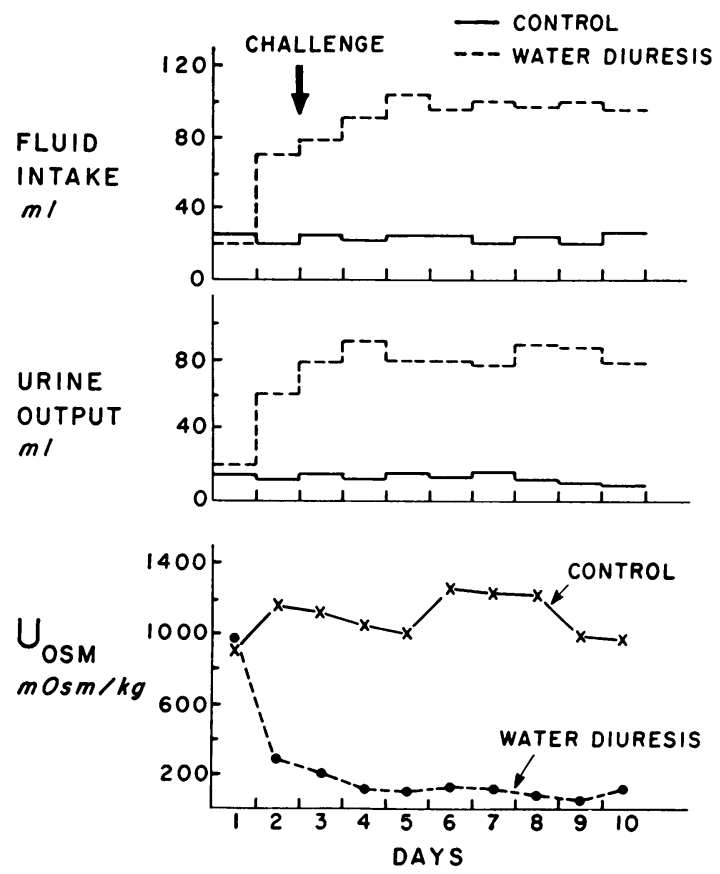

Fig. 1. Mean daily levels of water intake, URINARY OUTPUT, AND URINARY OSMOLALITY (U⿴囗十) IN 38 CONTROL RATS FED AD LIBITUM AND 41 RATS GIVEN $5 \%$ GLUCOSE TO DRINK. The arrow marked "challenge" indicates the time of Candida or Staphylococcal inoculation.
TABLE I

Prevention of Candida pyelonephritis by water diuresis

\begin{tabular}{ccc}
\hline \multicolumn{1}{c}{ Candida } & $\begin{array}{c}\text { Infected/ } \\
\text { Total* }\end{array}$ & $\mathrm{p}$ \\
\hline Control & $16 / 17$ & \\
$\begin{array}{c}\text { Diuresis begun } \\
\text { 1 day before } \\
\text { inoculation }\end{array}$ & $3 / 17$ & $<0.01$ \\
\hline
\end{tabular}

* The total number of rats inoculated intravenously with $10^{6}$ Candida albicans cells is shown, together with the number of rats in each group that developed infection of the renal parenchyma.

when organisms were found in the blood agar pour plates.

Chemical studies of the renal medulla. The composition of the renal medulla was determined in rats during water diuresis and compared to control animals fed ad libitum. Rats undergoing water diuresis were anesthetized with alcohol, and a suitable period was allowed for inhibition of antidiuretic hormone by alcohol before the kidneys were removed. The kidneys were sectioned longitudinally and slightly off center so that free access to the papilla and medulla was obtained. The entire white medullas of two kidneys (weight, 30 to $60 \mathrm{mg}$ ) were weighed, placed in $5 \mathrm{ml}$ of distilled water, and homogenized with a motor-driven Teflon pestle. Pieces of cortex weighing 250 to $400 \mathrm{mg}$ were homogenized in $10 \mathrm{ml}$ of water. Immediately after homogenizing, samples were removed for duplicate analyses of urea and ammonium (13). The homogenate was then heated at $100^{\circ} \mathrm{C}$ for 1 hour, cooled, and centrifuged, and analyses for sodium and potassium were done in duplicate on the supernatant fluid with a flame photometer. The water content of similar pieces of medulla and cortex was determined by weighing before and after dessication at $95^{\circ} \mathrm{C}$ for 48 hours.

"Total solute" concentration in tissue was calculated as $2\left(\mathrm{Na}^{+}+\mathrm{K}^{+}+\mathrm{NH}_{4}^{+}\right)+$urea, where $\mathrm{Na},{ }^{+} \mathrm{K},{ }^{+} \mathrm{NH}_{4}{ }^{+}$ and urea are expressed as mmoles per $\mathrm{kg}$ tissue water.

\section{Results}

Water diuresis produced by glucose ingestion. The mean daily levels of water intake, urinary output, and urinary osmolality in 38 control animals fed ad libitum and 41 rats given $5 \%$ glucose to drink are shown in Figure 1. The first day's values are base-line observations. Rats continually drink large amounts of glucose water, apparently because they like it. The glucose ingested is presumably metabolized, since glucose does not appear in the urine or in abnormal amounts in the blood. The average blood sugar in five rats drinking glucose for 2 days was $138 \mathrm{mg}$ per 100 
$\mathrm{ml}$ as compared to $142 \mathrm{mg}$ per $100 \mathrm{ml}$ in four rats drinking water. Water intake and urinary output increased several fold. Urinary osmolality dropped below 200 and frequently below $100 \mathrm{mOsm}$ per $\mathrm{kg}$. The $\mathrm{pH}$ of urine samples from control animals had a mean value of 7.14 as compared to an average of 7.88 for animals undergoing water diuresis. The weights of control rats at the beginning and end of the study period did not differ significantly from those given glucose.

Candida pyelonephritis (Table I). An inoculum of Candida was injected into both groups at the point marked "challenge" in Figure 1. When the rats were killed 8 days later, pyelonephritis was observed in 16 of 17 control animals and in only three of 17 rats undergoing water diuresis. Gross abscesses, commonly seen in the kidneys of control animals, were absent in the kidneys of the three infected rats undergoing water diuresis.

Staphylococcal pyelonephritis (Table II, Figures 2 and 3 ). The incidence and severity of Staphylococcal pyelonephritis were also diminished by water diuresis. Pyelonephritis was observed in 20 of 21 control animals. Rats were protected from renal infection when water diuresis was begun 1 day before or 1 day after Staphylococcal inoculation, since only three of 12 and four of 12 animals, respectively, were infected. When diuresis was begun as late as 3 days after inoculation, infection was found in only six of 13 rats killed 5 days later. Since renal parenchymal infection and abscess formation are known to occur regularly between 24 and 48

TABLE II

Effect of water diuresis in preventing Staphylococcal infection of the kidneys

\begin{tabular}{lcc}
\hline \multicolumn{1}{c}{ Staphylococcus* } & $\begin{array}{c}\text { Infected/ } \\
\text { Total }\end{array}$ & $\mathrm{p}$ \\
\hline Control & $20 / 21$ & \\
$\begin{array}{c}\text { Diuresis begun 1 day } \\
\text { before inoculation }\end{array}$ & $3 / 12$ & $<0.01$ \\
$\begin{array}{c}\text { Diuresis begun 1 day } \\
\text { after inoculation }\end{array}$ & $4 / 12$ & $<0.01$ \\
$\begin{array}{c}\text { Diuresis begun 3 days } \\
\text { after inoculation }\end{array}$ & $6 / 13$ & $<0.01$ \\
$\begin{array}{c}\text { Diuresis begun 5 days } \\
\text { after inoculation }\end{array}$ & $6 / 8$ & $0.50-0.30$ \\
\hline
\end{tabular}

* $10^{8}$ Staphylococcus aureus cells were injected intravenously at the time of inoculation.

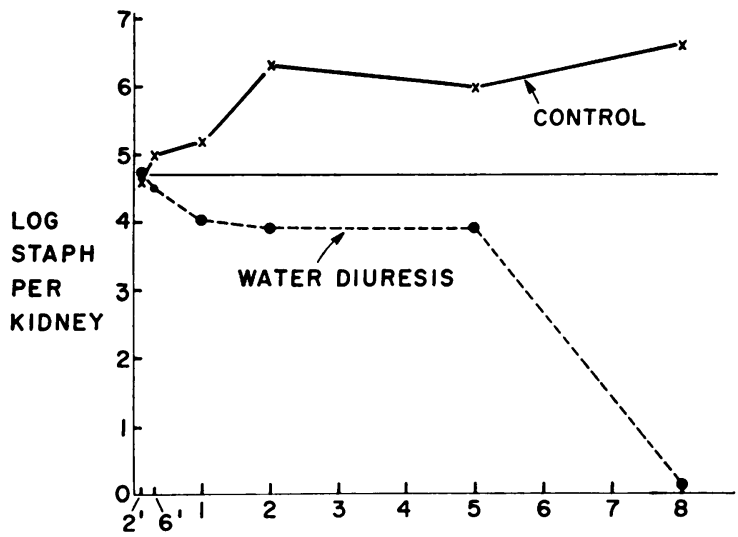

Fig. 2. EFFECT OF WATER DIURESIS ON THE NUMBER OF STAPHYLOCOCCI REMAINING IN THE KIDNEY AFTER INTRAVENOUS INOCULATION. Each point represents the log of the median number of Staphylococci (ordinate) recovered from 12 kidneys at intervals of hours and days (abscissa) after intravenous challenge.

hours after intravenous challenge with this strain of Staphylococcus (12), some rats in this group must have been cured of their infection. Although renal infection was not prevented or cured by water diuresis begun 5 days after intravenous Staphylococcal challenge, animals in this group had sustained a water diuresis for only 3 days, since they were killed 8 days after inoculation.

Water diuresis may alter the normal distribution of blood flow to the kidney $(14,15)$. Therefore, it was essential to determine whether water diuresis altered the number of organisms initially deposited in the kidney. Groups of six controls and six rats undergoing diuresis were killed at intervals after intravenous Staphylococcal challenge. The results of quantitative cultures of kidney homogenates are plotted in Figure 2. Each point represents the $\log$ of the median number of organisms recovered from 12 kidneys in each group. The horizontal line represents the log of 50,000 . Colony counts per kidney at or above this number, when observed 8 days after challenge, have been shown to reflect renal parenchymal infection and abscess formation in previous studies $(11,12)$.

The number of organisms present in the kidneys of controls and animals undergoing diuresis 2 and 6 hours after inoculation was almost identical. At 1 day there was more than a $\log$ difference, which remained until the eighth day when viable Staphylococci were no longer detectable in kid- 


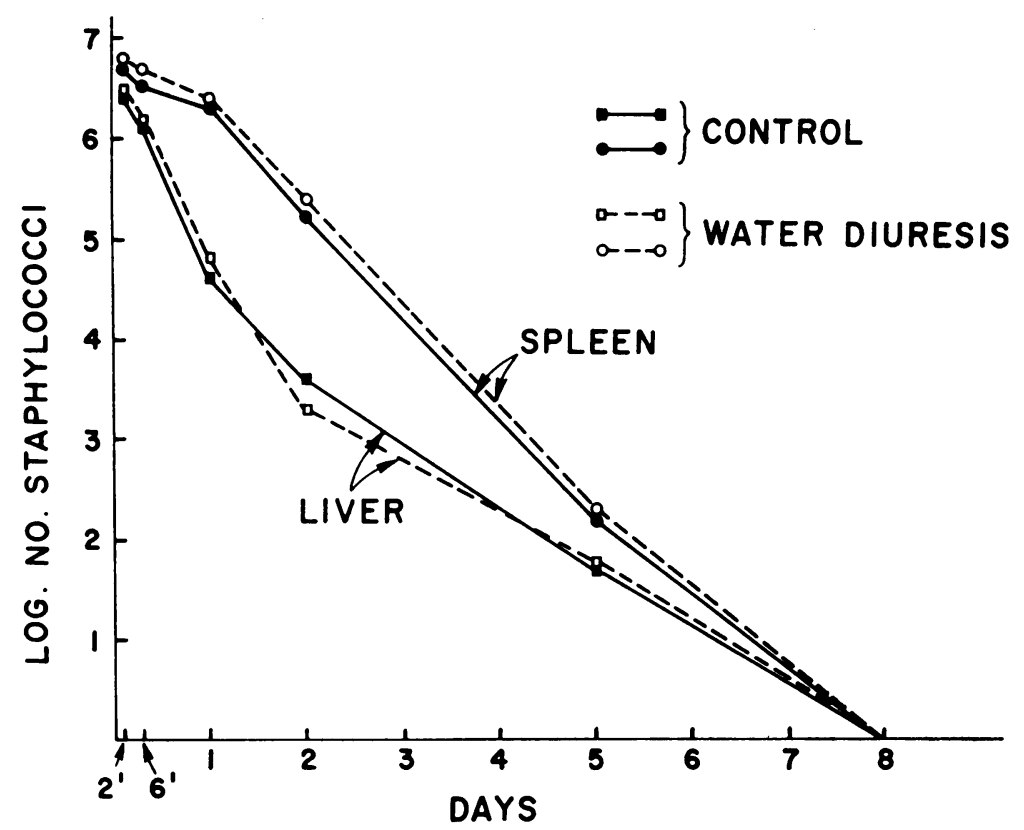

Fig. 3. EFFEct OF WATER DIURESis ON THE NUMBER OF STAPHylococci REMAINING IN THE LIVER AND SPLEEN AFTER INTRAVENOUS INOCULATION. Each point represents the log of the mean number of Staphylococci (ordinate) recovered from the liver or spleen of six rats at intervals of hours and days (abscissa) after intravenous challenge.

neys undergoing diuresis. Staphylococci did not appear in the urine of control rats until 1 day after inoculation, a time when renal parenchymal infection was grossly obvious. Staphylococci never appeared in the urine of rats undergoing water diuresis. These observations demonstrate that water diuresis does not merely wash organisms out of the kidney into the urine.

In contrast to the counts in kidney, colony counts of viable Staphylococci in liver and spleen of control rats and animals undergoing diuresis were similar when compared at these same intervals (Figure 3 ).

To determine whether the renal medulla of animals undergoing water diuresis elaborated a bactericidal substance, extracts of renal medulla from controls and animals underging diuresis were separately mixed with ten Staphylococcal organisms in sterile test tubes containing broth, placed on a rotator, and incubated at $37^{\circ} \mathrm{C}$ for 24 hours. The growth rate of Staphylococci was determined by pour plate colony counts of serial 100 -fold di-

TABLE III

Effect of water diuresis on the compositon of renal medulla and cortex*

\begin{tabular}{|c|c|c|c|c|c|c|c|c|c|c|c|c|c|c|}
\hline & \multicolumn{6}{|c|}{ Medulla } & \multicolumn{6}{|c|}{ Cortex } & \multicolumn{2}{|c|}{ Urine } \\
\hline & \multicolumn{2}{|c|}{$\mathrm{Na}$} & \multirow{2}{*}{$\begin{array}{c}\mathrm{K} \\
\begin{array}{c}m E q / \\
k g \\
H_{2} O\end{array}\end{array}$} & \multirow{2}{*}{$\begin{array}{c}\mathrm{NH}_{4} \\
\begin{array}{c}m E q / \\
k g \\
\mathrm{H}_{2} \mathrm{O}\end{array}\end{array}$} & \multirow{2}{*}{$\frac{\text { Urea }}{\underset{\mathrm{kg} \mathrm{H} \mathrm{H}_{2} \mathrm{O}}{\mathrm{mmoles} /}}$} & \multirow{2}{*}{$\frac{\begin{array}{c}\text { Total } \\
\text { solute }\end{array}}{{\underset{\mathrm{kg} \mathrm{H}}{\mathrm{mmoles} /}}_{2} \mathrm{O}}$} & \multicolumn{2}{|c|}{$\mathrm{Na}$} & \multirow{2}{*}{$\frac{\mathrm{K}}{\underset{k \mathrm{mE} \mathrm{H} \mathrm{H}_{2} \mathrm{O}}{m \mathrm{O}^{\prime}}}$} & \multirow{2}{*}{$\frac{\mathrm{NH}_{4}}{\underset{k g \mathrm{H}_{2} \mathrm{O}}{m \mathrm{I}}}$} & \multirow{2}{*}{$\begin{array}{c}\text { Urea } \\
\underset{\mathrm{kg} \mathrm{H} \mathrm{H}_{2} \mathrm{O}}{\mathrm{mmoles}}\end{array}$} & \multirow{2}{*}{$\frac{\begin{array}{c}\text { Total } \\
\text { solute }\end{array}}{\stackrel{m}{\mathrm{mmoles} /}}$} & \multirow{2}{*}{$\frac{\text { Uosm }}{{\underset{k g ~ H}{m} \mathrm{H}_{2} \mathrm{O}}^{\mathrm{m} m /}}$} & \multirow{2}{*}{$\frac{\text { Urea }}{\underbrace{\text { mmoles } /}_{L}}$} \\
\hline & $\underset{k g \mathrm{H}_{2} \mathrm{O}}{m E q}$ & $\begin{array}{c}m E q / \\
100 \mathrm{~g} \\
D S\end{array}$ & & & & & $\underset{k g \mathrm{H}_{2} \mathrm{O}}{m{ }^{\prime}}$ & $\begin{array}{c}m E q / \\
100 \mathrm{~g} \\
D S\end{array}$ & & & & & & \\
\hline \multirow{2}{*}{$\begin{array}{l}\text { Water } \\
\text { diuresis } \\
\qquad \begin{array}{l}12 \text { rats } \\
n=6\end{array}\end{array}$} & 123 & 83 & 60 & 23 & 62 & 476 & 61 & 22 & 92 & 35 & 20 & 389 & 219 & 16 \\
\hline & \pm 23 & \pm 13 & \pm 6 & \pm 6 & \pm 40 & \pm 92 & \pm 5 & \pm 1.5 & \pm 6 & \pm 5 & \pm 6 & \pm 39 & \pm 98 & \pm 10 \\
\hline \multirow{2}{*}{$\begin{array}{l}\text { Control } \\
\begin{array}{l}12 \text { rats } \\
n=6\end{array} \\
p\end{array}$} & $\begin{array}{r}215 \\
\pm 21\end{array}$ & $\begin{array}{r}120 \\
\pm 21\end{array}$ & $\begin{array}{r}61 \\
\pm 9\end{array}$ & $\begin{array}{r}30 \\
\pm 16\end{array}$ & $\begin{array}{r}489 \\
\pm 127\end{array}$ & $\begin{array}{l}1,101 \\
\pm 152\end{array}$ & $\begin{array}{r}68 \\
\pm 4\end{array}$ & $\begin{array}{r}23 \\
\pm 4\end{array}$ & $\begin{array}{r}100 \\
\pm 10\end{array}$ & $\begin{array}{r}27 \\
\pm 6\end{array}$ & $\begin{array}{r}16 \\
\pm 8\end{array}$ & $\begin{array}{r}408 \\
\pm 23\end{array}$ & $\begin{array}{l}2,004 \\
\pm 740\end{array}$ & $\begin{array}{l}1,232 \\
\pm 500\end{array}$ \\
\hline & $<0.01$ & $<0.01$ & NS & NS & $<0.01$ & $<0.01$ & $<0.01$ & NS & $<0.01$ & $<0.01$ & $<0.02$ & NS & $<0.01$ & $<0.01$ \\
\hline
\end{tabular}




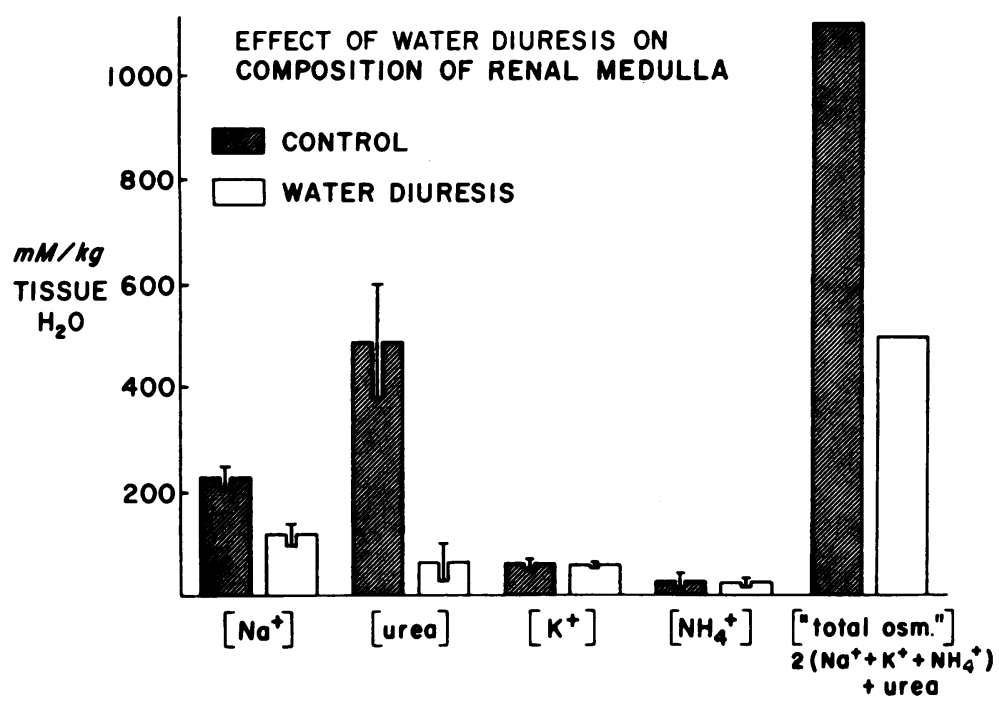

Fig. 4. EFFect OF WATER DIURESIS ON THE COMPOSITION OF THE RENAL MEDULLA. Medullary concentration of sodium, potassium, ammonia, urea, and total calculated solutes in control (normal) rats and rats undergoing water diuresis.

lutions. Extracts of renal medulla from animals undergoing diuresis did not inhibit bacterial growth.

Chemical composition of the renal medulla and cortex. (Table III and Figure 4). Water diuresis was associated with a fall in the concentration of sodium in inner medullary tissue from $215 \pm 21$ to $123 \pm 23 \mathrm{mEq}$ per $\mathrm{kg}$ of tissue water. The concentration of urea, which averaged $489 \pm$ 127 mmoles per $\mathrm{kg}$ of tissue water in control rats, declined to $62 \pm 40$ mmoles per $\mathrm{kg}$ in rats undergoing water diuresis. As in dogs during water diuresis (16), the content of sodium and urea per $100 \mathrm{~g}$ of dry solids in medullary tissue also decreased. Tissue concentrations of potassium and ammonium were unchanged by water diuresis. Total calculated osmolality of medullary tissue was reduced by water diuresis from 1,101 to 476 mOsm per $\mathrm{kg}$.

In contrast to medullary tissue, total solute concentration of the cortex was unaltered by water diuresis. Sodium and potassium concentrations in the water of cortical tissue fell slightly, whereas ammonium and urea levels rose.

Histology. Serial sections of kidneys from control rats examined histologically 24 and 48 hours after Staphylococcal challenge showed numerous microabscesses in the cortex and medulla. Clumps of Staphylococci were observed in the center of medullary abscesses. In contrast, the medulla of the kidneys of rats undergoing diuresis was relatively normal at 24 and 48 hours, even though the cortex contained a few focal areas of inflammatory cells.

\section{Discussion}

These studies in the rat demonstrate that Candida and Staphylococcal renal parenchymal infection can be prevented, and suggest that Staphylococcal renal infection can be cured by decreasing the normally hypertonic environment of the renal medulla through sustained water diuresis. The data, together with much more accumulated previously by others (16-21), indicate that the blood and interstitial fluids of the medulla are hypertonic when the urine is concentrated, but approximate isotonicity during water diuresis.

The organisms used in the present study, although not common causes of human pyelonephritis, were specifically chosen because they consistently produce acute pyelonephritis in the nonmanipulated rat kidney. Although several types of renal and extrarenal manipulations have been shown to predispose the kidneys of experimental animals to pyelonephritis, these models were not used in the present study in an attempt to eliminate the possible effects of the predisposing injury on the chemical composition of the kidney, 
and on the delivery and function of phagocytes and other serum factors that contribute to the normal defenses of the renal medulla.

The decreased incidence and severity of renal infection observed in rats undergoing water diuresis was clearly not due to an inadequate number of organisms initially deposited in the kidney, nor did water diuresis merely wash organisms out of the kidney into the urine of these animals. The decreased susceptibility to infection of the kidneys of rats undergoing water diuresis did not appear to result from a bactericidal substance in the renal medulla induced by diuresis, since extracts of renal medulla from animals undergoing diuresis did not contain a substance bactericidal for Staphylococci.

There are a number of possible mechanisms by which hypertonicity might enhance the vulnerability of the medulla to infection. Originally Hamburger (22) noted that hypertonic saline solutions inhibit phagocytosis. More recently, Chernew and Braude (23) observed that concentrations of sodium and of urea, within the range normally found in the renal medulla, inhibit phagocytosis of Escherichia coli by human leukocytes. Highly concentrated human urine similarly depresses phagocytosis, whereas more dilute urines do not. Hypertonic saline has also been shown to inhibit the activity of complement (24). Perhaps both phagocytosis and complement activity are enabled to proceed normally in the medulla of the rat undergoing water diuresis, but are inhibited in the medulla of the hydropenic animal.

Since water diuresis increases renal medullary blood flow $(14,15)$, a third explanation may lie with the more rapid delivery, during water diuresis, of greater numbers of phagocytes and other serum factors that contribute to the natural defenses of the body. However, increased numbers of phagocytes were not observed in the medulla when the kidneys of animals undergoing diuresis were examined histologically at various intervals after Staphylococcal challenge.

Finally, these natural defenses, namely, antibody, complement, and lysozyme, can injure the cell wall of most urinary pathogens so that they form protoplasts (25-27). These protoplasts are lysed in a hypotonic or isotonic environment, but are preserved in hypertonic solutions (28). Protoplasts would presumably be lysed in the iso- tonic environment of the medulla during water diuresis.

Although we have no direct evidence to support these possible mechanisms, the results of our studies do support the view that the hypertonic environment of the renal medulla is important in the development of pyelonephritis. They thus provide an experimental rationale for the timehonored practice of "forcing fluids" in patients with urinary infection. When hypertonicity is overcome by water diuresis, experimental renal infections may be prevented or greatly ameliorated.

\section{Summary}

Chronic water diuresis was induced in rats by adding glucose to their drinking water. The concentrations of sodium and urea and the total calculated osmolality of inner medulla were significantly reduced by water diuresis, whereas tissue concentrations of ammonia and potassium were unchanged.

Water diuresis protected against two types of experimental pyelonephritis, that produced by intravenous inoculation of Candida albicans and of Staphylococcus aureus.

These data support the view that the habitual hypertonicity of the renal medulla is an important determinant of the special susceptibility of this tissue to infection.

\section{Acknowledgments}

We gratefully acknowledge the technical assistance of Ellen Cooper, Penny Howe, Nancy Sudvoy, and Nadia Mykety.

\section{References}

1. Rocha, H., L. B. Guze, L. R. Freedman, and P. B. Beeson. Experimental pyelonephritis. III. The influence of localized injury in different parts of the kidney on susceptibility to bacillary infection. Yale J. Biol. Med. 1958, 30, 341.

2. Freedman, L. R., and P. B. Beeson. Experimental pyelonephritis. IV. Observations on infections resulting from direct inoculation of bacteria in different zones of the kidney. Yale J. Biol. Med. 1958, 30, 406.

3. Rocha, H., L. B. Guze, and P. B. Beeson. Experimental pyelonephritis. V. Susceptibility of rats to hematogenous pyelonephritis following chemical injury of the kidneys. Yale J. Biol. Med. 1959, 32, 120. 
4. Freedman, L. R. Experimental pyelonephritis. VI. Observations on susceptibility of the rabbit kidney to infection by a virulent strain of Staphylococcus aureus. Yale J. Biol. Med. 1960, 32, 272.

5. Guze, L. B., B. H. Goldner, and G. M. Kalmanson. Pyelonephritis. I. Observations on the course of chronic non-obstructed enterococcal infection in the kidney of the rat. Yale J. Biol. Med. 1961, 33, 372.

6. Beeson, P. B. Factors in the pathogenesis of pyelonephritis. Yale J. Biol. Med. 1955, 28, 81.

7. Rocha, H., and F. R. Fekety, Jr. Acute inflammation in the renal cortex and medulla following thermal injury. J. exp. Med. 1964, 119, 131.

8. Beeson, P. B., and D. Rowley. The anticomplementary effect of kidney tissue. Its association with ammonia production. J. exp. Med. 1959, 110, 685.

9. Fister, H. J. Manual of Standardized Procedures for Spectrophotometric Chemistry. New York, Standard Scientific Supply Corp., 1950.

10. Andriole, V. T., and H. F. Hasenclever. Factors influencing experimental candidiasis in mice. I. Alloxan diabetes. Yale J. Biol. Med. 1962, 35, 96.

11. Andriole, V. T. The pathogenesis of candidiasis in the rat. In preparation.

12. Freedman, L. R., A. S. Werner, D. Beck, and S. Paplanus. Experimental pyelonephritis. IX. The bacteriological course and morphological consequences of staphylococcal pyelonephritis in the rat, with consideration of the specificity of the pathological changes observed. Yale J. Biol. Med. 1961, 34, 40.

13. Conway, E. J. Microdiffusion Analysis and Volumetric Error, 4th ed. London, Crosby Lockwood, 1957.

14. Ullrich, K. J., K. Kramer, and J. W. Boylan. Present knowledge of the countercurrent system in the mammalian kidney. Progr. cardiovasc. Dis. 1961, 3, 395.

15. Thurau, K., P. Deetjen, and K. Kramer. Hämodynamik des Nierenmarks. II. Mitteilung. Wechselbeziehung zwischen vascularem und tubularem Gegenstrom-system bei arteriellen Drucksteigerungen, Wasserdiuresis und osmotischer Diuresis. Pflügers Arch. ges. Physiol. 1960, 270, 270.
16. Levitin, H., A. Goodman, G. Pigeon, and F. H. Epstein. Composition of the renal medulla during water diuresis. J. clin. Invest. 1962, 41, 1145.

17. Ullrich, K. J., and K. H. Jarausch. Untersuchungen zum Problem der Harnkonzentrierung und Harnverdünnung; uber die Verteilung von Elektrolyten ( $\mathrm{Na}, \mathrm{K}, \mathrm{Ca}, \mathrm{Mg}, \mathrm{Cl}$, anorganischem Phosphat), Harnstoff, Aminosäuren und exogenen Kreatinin in Rinde und Mark der Hundeniere bei verschiedenen Diuresezuständen. Pflügers Arch. ges. Physiol. 1956, 262, 537.

18. Gottschalk, C. W. Micropuncture studies of tubular function in the mammalian kidney. Physiologist 1961, 4, 35.

19. Bray, G. A. Freezing point depression of rat kidney slices during water diuresis and antidiuresis. Amer. J. Physiol. 1960, 199, 915.

20. Ruiz-Guinazu, A., and E. E. Arrizurieta. La acción de la Pitresina sobre la formación del gradiente osmotico medular renal. Medicina (B. Aires) 1962, 23, 167.

21. Boylan, J. W., and E. Asshauer. Depletion and restoration of the medullary osmotic gradient in the dog kidney. Pflügers Arch. ges. Physiol. 1962, 276, 99.

22. Hamburger, H. J. Physikalisch-chemisch Untersuchungen über Phagozyten. Wiesbaden, 1912.

23. Chernew, I., and A. I. Braude. Depression of phagocytosis by solutes in concentrations found in the kidney and urine. J. clin. Invest. 1962, 41, 1945.

24. Kabat, E. A., and M. M. Mayer. Experimental Immunochemistry, 1st ed. Springfield, Ill., Charles C Thomas, 1948, p. 105.

25. Carey, W. F., L. H. Muschel, and L. S. Baron. The formation of bacterial protoplasts in vivo. J. Immunol. 1960, 84, 183.

26. Gilby, A. R., and A. V. Few. Osmotic properties of protoplasts of Micrococcus lysodeikticus. J. gen. Microbiol. 1959, 20, 321.

27. Mitchell, P., and J. Moyle. Liberation and osmotic properties of the protoplasts of Micrococcus Lysodeikticus and Sarcina lutea. J. gen. Microbiol. 1956, 15, 512.

28. Braude, A. I., J. Siemienski, and I. Jacobs. Protoplast formation in human urine. Trans. Ass. Amer. Phycns 1961, 74, 234. 